\title{
Lexical Bundles in Indonesian and English Undergraduate Thesis Abstracts
}

\author{
Maria Caroline Samodra \\ Language Institute of Sanata Dharma University \\ Yogyakarta, Indonesia \\ s.mariacaroline@gmail.com
}

\author{
Vincensia Dian Ratna Pratiwi \\ English Language Studies, Sanata Dharma University \\ Yogyakarta, Indonesia \\ vincensia.dian@gmail.com
}

\begin{abstract}
The present study investigates Indonesian and English lexical bundles (LBs) used by Indonesian learners in their thesis abstracts. It aims to examine (1) the most common lexical bundles in the Indonesian and English undergraduate thesis abstracts, (2) similarities/differences in terms of form and functions, and (3) possible factors for the use of LBs in the students' abstracts. The data were obtained from a corpus of 140 abstracts written by Indonesian undergraduate students from Natural Science and Social Science disciplines in several universities in Indonesia. Results show that LBs with the phrases penelitian ini and this research dominate the abstracts. Based on the form, Indonesian and English LBs are mostly similar in the way that the same words are used repetitively from one language to the other, such as dalam penelitian ini, which often becomes in this research. Functionally, research-oriented and text-oriented LBs dominate the abstracts in both languages while the participant-oriented ones are the least frequent LBs. It is implied that the LB usage is influenced by students' knowledge of academic conventions, students' proficiency on the English LBs, and the differences of the languages themselves. There are some implications for teachers and students regarding the use of LBs in academic writing.
\end{abstract}

Keywords—lexical bundles, abstracts, undergraduate, corpus

\section{INTRODUCTION}

According to Swales (1990:179), an abstract functions as the "front matter" and "summary" of the research, making them a standalone genre. The importance of the abstract is highly significant in the way that many readers choose to read the abstract before deciding whether to read the content of the research. It is also often the case that abstracts are translated from one language to English to enable wider communities. Therefore, it can be implied that high-quality abstracts interest the audience through the language used.

An aspect of abstracts which might affect how they are structured is lexical bundles, or co-occurring words. Research has shown that the lexical phrases identified in academic writing have functions dependent on its sections (e.g. Ngadiman 2013 and Cortes 2013), suggesting that LBs are also essential for writing an abstract. However, such specific distinctions in academic writing have tended to be overlooked; the majority of the LB studies have only focused on academic writing in general (e.g. Hyland 2008; Jalilifar et al. 2017) although most have shown striking differences among different communities. Due to the importance of abstracts in academic writing, this present study focuses on learners' use of LBs in their mother tongue (L1), Indonesian, and their second/foreign language (L2), English, in the undergraduate thesis abstracts to examine how abstracts are written in L2 in relation to their $\mathrm{L} 1$.

Three questions are addressed in the study, namely: 1) What are the most common lexical bundles in the Indonesian and English undergraduate thesis abstracts?, 2) How are the Indonesian and English lexical bundles similar/different in terms of form and functions? To what extent do the English LBs conform to the academic LB list?, and 3) What possibly influences the similarities/differences in the use of LBs in the Indonesian and English abstracts?.

\section{REVIEW OF LITERATURE}

Lexical bundles are important as they serve as building blocks for writing (Biber and Conrad 1999; Hyland 2008). Formulaic expressions have given rise to the increase of LB studies due to the advancement of corpus-based methodologies. Identifying the most frequent bundles enable the writers to analyse the discourse organisation (Cortes 2013: 35). In academic writing, knowing how to use fixed expressions can help promote cohesion of the texts.

Biber et al. (1999) define lexical bundles as three- or more word units that occur frequently and commonly go together. It is to be noted that the shorter bundles are often incorporated in the longer ones, for example: I don't think and well I don't think (ibid: 992). This definition has appeared to be the basis of other studies (e.g. Hyland 2008 \& Cortes 2013).

Hyland (2008) explored 4-word bundles in a corpus of academic texts (e.g. research articles, $\mathrm{PhD}$ theses, and MA dissertations). Drawing from his data, he classified 3 functions of lexical bundles: (1) research-oriented, (2), text-oriented, and (3) participant oriented. Generally, the most frequent bundles were the first two functions as his own study, also supported by Wei and Lei (2011), revealed so.

Following Hyland (2008), Jalilifar et al. (2017) attempted to invent a general lexical bundle list from a 6-million-word corpus of research articles from prestigious international journals. Nevertheless, in contrast to Hyland (2008), they found that most of the lexical phrases were text-oriented.

Research show that lexical bundles are used differently between native (NS) and non-native (NNS) writers. Chen and 
Baker (2010)investigated the LBs of native expert writing and non-native Chinese student writing. The results showed that the widest range of lexical bundles were available in native expert writing. Similarly, Adel and Erman (2012) studied NS and Swedish NNS writing and it revealed that the NS texts had more varied and wide-ranging bundles, for example existential there and unattended this.

Following the previous studies, Dontcheva-Navratilova (2012) analysed Czech students' diploma theses, which suggested that L1 transfer played an important role in the students' writing. The L1 interference on LBs was then confirmed by Paquot (2013), who discovered that learners' LB use could be traced back in their mother tongue, French.

Studies on lexical bundles in different languages also show cross-linguistic differences in how formulaic expressions are utilised. Granger (2014), for example, compared English and French parliamentary debates. The results indicated that the LBs of different languages varied in length, and that different genres have their own key bundles. For instance, the proportion of the 1st person pronoun in English parliamentary debate was significantly larger than that in French. Novita and Kwary (2018), in addition, investigated how students and professional writers translated LBs in a literary text from Indonesian into English. It was revealed that the proficiency level of the writer groups affected their production of LBs.

With the exception of Novita and Kwary (2018), there seems to be little attention to contrastive studies of lexical bundle among non-native speakers of English. Additionally, previous research on academic writing has tended to ignore the specific sections of academic papers, which, as Cortes (2013) discovered, influence the use of word combinations. Therefore, this present research aims to fill the gap by investigating the use of lexical bundles in Indonesian and English abstracts among Indonesian undergraduate students.

\section{METHODOLOGY}

This research used the corpus-based approach (McEnery et al. 2006: 10), which, in nature, is quantitative and qualitative. Quantitatively, the frequency counts of the English and Indonesian LB list were relied on to determine the most common bundles comprising each language's abstracts. Qualitative interpretation was conducted by analysing the LB list and comparing it to the pre-existing LB list by Jalilifar et al. (2017) and discussing LB functions identified in the abstracts.

\section{A. Corpus}

The data were taken from a total of 140 Indonesian and English abstracts in the undergraduate theses from various universities in Indonesia written in 2016-2018. The English abstracts were the translated version of the Indonesian abstracts to fit the aims of the present study. Analysing parallel texts, or the same texts written in different languages, as Baker (1995) suggests, might shed light to how writers compose in a foreign language in relation to their first language.
The discipline differences were not taken into account as the purpose of this research was to obtain core patterns of the bundles. However, for the data to be balanced, as McEnery et al. (2006: 19) suggest, respectively 36 and 34 texts from Natural and Social Sciences were chosen using a purposive random sampling technique. Table 1 shows the composition of the corpus of Indonesian and English abstracts.

TABLE 1.Corpus of Indonesian and English abstracts

\begin{tabular}{|c|r|r|r|r|}
\hline \multirow{2}{*}{ Disciplines } & \multicolumn{2}{|c|}{ Indonesian(TXT) } & \multicolumn{2}{c|}{ English (TXTRANS) } \\
\cline { 2 - 5 } & $\begin{array}{c}\text { No. of } \\
\text { text }\end{array}$ & $\begin{array}{c}\text { No. of } \\
\text { words }\end{array}$ & No. of text & No. of words \\
\hline Natural Science & 36 & 8175 & 36 & 8879 \\
\hline Social Science & 34 & 7314 & 34 & 8241 \\
\hline TOTAL & 70 & 15489 & 70 & 17120 \\
\hline
\end{tabular}

\section{B. Research Procedure}

Adapted from Lee (2013), four steps were taken to answer the research questions.

\section{1) 1. Extracting LBs from English and Indonesian} abstracts

3-word and 4-word bundles were extracted from the corpus using AntConc, a concordancing software (Anthony 2014). The LBs which occurred more than 3 times in more than 3 abstracts were extracted to identify the representation of the most common bundles in the abstracts. The reason for choosing the cutoff point is to avoid idiosyncrasies of the writers (Biber et al. 2004).

\section{2) Selecting LBs which are relevant to the research} purposes

To obtain the general tendency of the word combinations, the discipline-specific bundles were eliminated, for example: organic rice farming. With such bundles eliminated, the list would reveal the core word combinations throughout the abstracts.

\section{3) Organising the data}

Similar to those of Hyland (2008) and Jalilifar et al. (2017), the LBs were first organised based on frequency ranks. Next, the functions were determined by categorising each bundle into research-, text-, and participant-oriented bundles (Hyland 2008). To ensure validity of the function categorisation, both researchers had to reach an agreement in coding the LBs.

\section{4) Interpreting the data}

Interpretation was made by observing the frequency ranks, similarities/differences, and functions. As the sizes of the two corpora are different, the frequencies were normalised to per 10,000 words to make them directly comparable. As suggested by McEnery and Hardie (2012), the formula for normalising the frequencies was:

$\mathrm{F} / 10,000=\frac{\text { LB raw frequency }}{\text { number of words in the subcorpus }} \times 10,000$

Since Jalilifar et al.(2017) by far have created the most comprehensive English LB list in academic writing, the English LBs in the abstracts were compared to the list (see 
Appendix 2) to see to what extent the students'L2 writing conforms to the English academic conventions.

\section{RESULTS AND DISCUSSION}

\section{A. Most Common Lexical Bundles}

There are 551 Indonesian 3- and 4-word LBs $(F / 10,000=356.01)$ and 674 English LBs $(F / 10,000=393.69)$ identified in the abstracts. Due to space constraints, Table 2 (see Appendix 1) shows only the twenty most frequent bundles in Indonesian and English. Based on the table, it can be seen that the Indonesian and English LBs are highly similar in the way that the LBs are dominated by the phrases penelitian ini and this research. For example, the most common 3-word LBs in the Indonesian abstracts are penelitian ini adalah $(\mathrm{F} / 10,000=29.72)$ and dalam penelitian ini $(\mathrm{F} / 10,000=21.97)$. Similarly, the English counterpart this research is $(\mathrm{F} / 10,000=21.03)$ and of this research is $(\mathrm{F} / 10,000=10.51)$ are the most frequent 3 - and 4-word bundles respectively.

\section{B. Lexical Bundle: Forms and Functions}

\section{1) Forms of $L B$}

The data show that there is a great number of Indonesian LB patterns retained in their English structures. For instance, the phrase dalam penelitian ini (1) possesses the same structure in the English version as in this research (2), noticed to be used repetitively in different texts.

(1) Metode penelitian yang digunakan dalam penelitian ini adalah metode kualitatif. Pendekatan dalam penelitian ini adalah menggunakan pendekatan deskriptif kualitatif. Teknik pengumpulan data dalam penelitian ini yaitu observasi, wawancara dan dokumentasi. (TXT 21)

(2) The approach in this research is qualitative descriptive approach. The collecting data techniques in this research are observation, interview and documentation. (TXTRANS 21)

However, compared to the LB lists by Jalilifar et al. (2017) and Hyland (2008), the phrase with this research is not a frequently used bundle by expert writers. Instead, it is more common to use in this study and in this paper, as indicated by its high rank in the list. Therefore, it is obvious that this research is idiosyncratic to Indonesian undergraduate writers of the current study.

Other frequently used LBs in the Indonesian abstracts are the ones with untuk mengetahui, as in bertujuan untuk mengetahui and ini bertujuan untuk mengetahui. Surprisingly, the English correspondences are somewhat similar through the use of to know the, is to know, is to know the, and research is to know as can be seen in (3), (4), (5), and (6). Although other variations such as is to determine, is to describe and is to analyse can also be identified, it was less frequent than the LBs with to know.
(3) Penelitian ini bertujuan untuk mengetahui peran word of mouth dalam membentuk fanatisme masyarakat Kota Padang pada batu akik. (TXT 21)

(4) The purpose of this research is to know the rolw [sic] of word of mouth in shaping Padang City society fanaticism to akik stone. (TXTRANS 21)

(5) Tujuan penelitian ini adalah mengetahui gambaran happiness pada individu... (TXT 69)

(6) The goal of this research is to know the picture of happiness in the three informants... (TXTRANS 69)

Those bundles are not common and natural in the English academic discourse since they do not exist in the academic LB lists (Jalilifar et al. 2017). Thus, it could be inferred that the phrase untuk mengetahui and the English counterpart to know are typical of Indonesian abstracts.

Apart from the similarities, a few LB differences are observed in the occurrence of lexical phrases with high frequencies in one language but low in the other. As an instance, one of the, which is also common in the academic LB list (Jalilifar et al. 2017), is the second most frequent LB in the English abstracts. Yet, the Indonesian LBs with the phrase salah satu (merupakan salah satu, adalah salah satu, and sebagai salah satu) have a relatively low rank, meaning that they are not commonly used in Indonesian. Example (7) shows how one of the is used in one of the texts.

(7) One of the idea to distract children to watch animation movie (TXTRANS 15)

Besides (7), there are other incorrect forms in the English abstracts such as one of effort and one of many technique. In this case, the low rank of Indonesian LBs with salah satu might cause the wrong use of one of because they are not familiar with how it is used in English. In Indonesian, salah satu is not followed by plural forms; this might have contributed to their mistakes for not using plural forms following one of. In this case, language transfer, as Dontcheva-Navratilova (2012) and Paquot (2013) suggest, might contribute to ungrammatical bundles discovered in the data.

Another small proportion of LBs simply show differences between languages; they exist only in one language, but not in the other. For example, in (8) and (9), in the form of is realised as berupa, which is not a lexical bundle.

(8) Hasil yang diperoleh berupa peta parameter-parameter yang diasumsikan mempengaruhi potensi karbon monoksida... (TXT 27)

(9) The results obtained in the form of maps of parameters assumed to influence carbon monoxide... (TXTRANS 27) 


\section{2) Functions of $L B$}

Fig. 1 shows the percentage of LBs based on the functions proposed by Hyland (2008). The most frequent LB functions in Indonesian and English abstracts are research-oriented and text-oriented while the least popular bundles are participantoriented. This is in line with Wei and Lei (2011) in terms of the rank of the LB functions.

Fig. 1. Percentage of LB functional types

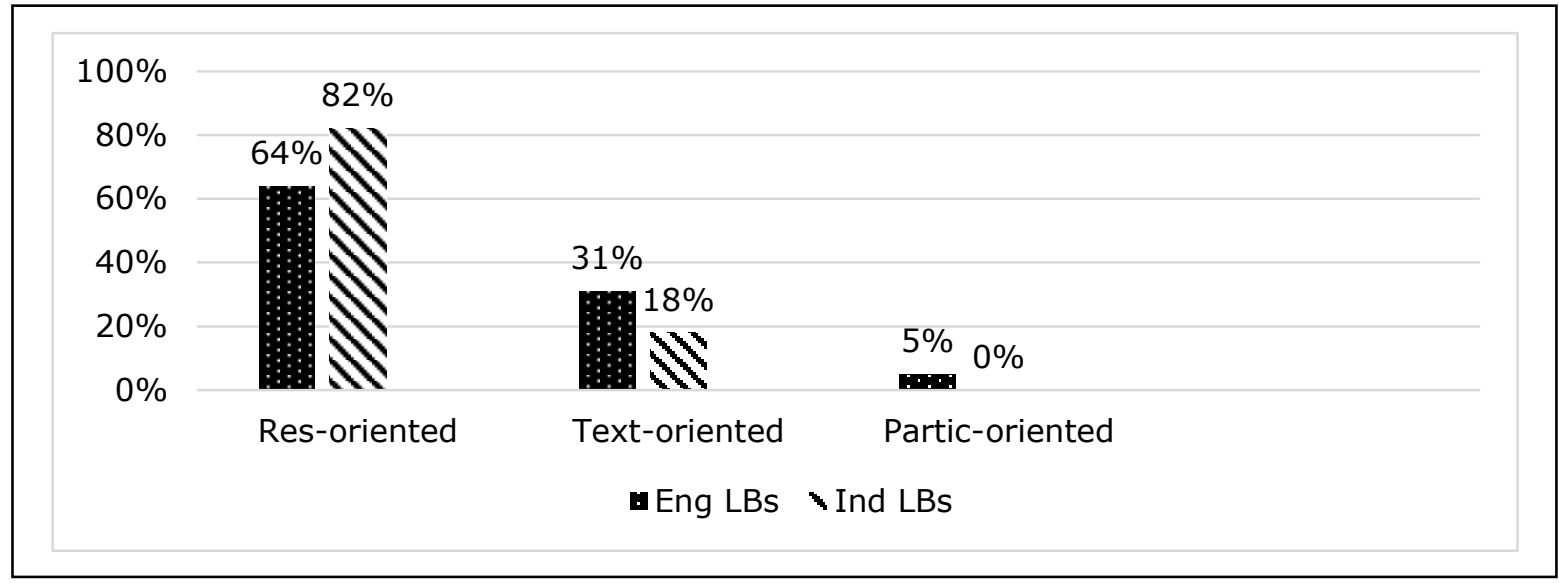

\section{a) Research-Oriented Bundles}

Bundles functioning to describe the study such as penelitian ini adalah and this research is dominate the results at $64 \%$ and $82 \%$ respectively. Indonesian abstracts have more frequent research-oriented LBs than the English texts. This result is similar to that of Wei and Lei (2011) since, in their study, the bundles functioning to elaborate or describe the research had the highest frequencies.

As an example of this, the writers might wish the reader to pay attention to the elements of the research. A number of the bundles signify the purposes or method as in (10) and (11).

(10) The purpose of this research is clustering emissions sources from several objects by single linkage of hierarchical method in Surakarta (TXTRANS 17)

(11) Subjek penelitian ini adalah individu yang berusia 20 25 tahun... (TXT 63)

In addition, similar to Hyland (2008), both in Indonesian and English, the bundle can function to elaborate the procedure of the research as in (12) and (13).

(12) Metode penelitian yang digunakan dalam penelitian ini adalah metode kualitatif. (TXT 21)

(13) The method that is used in this research is qualitative method (TXTRANS 21)

A reason for the frequent research-oriented bundles in both languages might be the need for density of information in the abstracts.

\section{b) Text-oriented Bundles}

In contrast to the research-oriented bundles, the text-oriented bundles are more frequent in the English abstracts at $31 \%$ compared to the Indonesian text-oriented LBs, which accounts for $18 \%$ of the LB types. The function is mostly resultative, or to signal causative links (Hyland 2008: 14). As an example, the 3-word bundles in this research and dalam penelitian ini are the most frequent text-oriented bundles. As shown in (14) and (15), the bundles function to refer to the research.

(14) The methodical elements in this research are interpretation, heuristics, and description. (TXTRANS 24)

(15) Objek formal dalam penelitian ini dalah filsafat teknologi Don Ihde (TXT 33)

Another purpose identified is to connect ideas; however, this function seems significantly less common than the resultative function. For example, in Indonesian writers' abstracts, the most common English text-oriented bundle is based on the (16) and according to the.

(16) Based on the information above, the researcher wants to examine the production system on Processing Unit and Organic Rice Production Tani Mandiri (TXTRANS 6)

The most common Indonesian connectors functioning as textoriented bundles are oleh karena itu and maka dari itu, as can be seen in (17) and (18).

(17) Oleh karena itu, popularitas kambing sebagai hewan ternak semakin meningkat sehingga peminat terhadap usaha peternakan kambing semakin meningkat pula. (TXT 1)

(18) Maka dari itu dibutuhkannya sebuah sistem informasi yang memudahkan user menangani permasalahan tersebut dengan memberikan informasi yang tepat. (TXT 12) 
The appearance of the English/Indonesian bundles above does not necessarily mean that there are no such expressions identified in the other language. Further investigation shows that such bundles are not present in the form of lexical bundles correspondingly. For example, maka dari itu is realised as therefore. However, it is to be noted that the LBs and their exact correspondences have similar frequencies, showing writers' tendency to use the same words repeatedly.

\section{c) Participant-oriented Bundles}

In line with Hyland (2008) and Jalilifar et al. (2017), participant-oriented bundles are the least used combinations in the Indonesian and English abstracts. In English, it comprises $5 \%$ and there is no 3- or 4-word participant-oriented bundle identified in the Indonesian abstracts.

Most, if not all, of the participant-oriented statements use the bundle it can be to signal the writers' attitudes. In Indonesian, there are no 3- or 4-word bundles that can be categorised as participant-oriented. However, a closer examination suggests that its Indonesian counterpart is used in the form of the nonbundle dapat although its occurrence is also rare. Excerpts (19) and (20) show how the participant-oriented statements are made in English and Indonesian.

(19) it can be known whether the production process is... (TXTRANS 6)

(20) sehingga dapat diketahui apakah proses produksi .. (TXT 6)

The rather infrequent participant-oriented bundles in both languages and the use of expressions with can, which signals certainty, suggest that the writers might want to maintain the objectivity of the texts. As Hyland (2008: 19) states, the avoidance of participant-oriented bundles might have something to do with the mother languages which favour impersonality.

\section{Factors Influencing Lexical Bundle Use}

The first cause might be the students' knowledge of Indonesian and English academic conventions. Based on the data, it could be assumed that the students learned fixed expressions due to the repeated LBs in both languages. Besides that, transfer of L1 knowledge might also contribute to the English LBs as can be seen in the seemingly retained L1 structure in the English LBs, resulting in unnatural use of English word combinations. Secondly, proficiency affects the students' English LBs in the abstracts as some LBs were found to be inaccurate such as the mistaken patterns following one of. Next, the differences of the languages themselves could contribute to the LBs of each language. For instance, a 3 -word LB in one language can be represented as one word in the other language e.g. oleh karena itu, which becomes therefore.

\section{Limitation of the Research}

This study has not accounted for the way each lexical bundle is translated. Besides that, it was not ensured whether or not the students wrote the abstracts by themselves.

\section{CONCLUSIONS AND RECOMMENDATIONS}

The data suggested that the differences between English and Indonesian lexical bundles were not highly significant. The LBs could be regarded similar in terms of the frequencies of the form and functions. However, it could be assumed that the writers of the abstracts were not aware of the academic conventions in the English writing as can be seen in the use of LBs which seem unsuitable for academic research, for example to know the. In addition, the repetitive LBs and inaccuracies of the English LB might signal the students' limited academic vocabulary.

Therefore, it is recommended that teachers of academic writing equip students with the lexical phrases necessary for writing the research abstracts. They can, for example, facilitate students to analyse the common patterns of academic writing LBs in the journal articles and utilise the suitable Academic Word List (AWL) to enrich their vocabulary.

\section{References}

Adel, A. \& Erman, B. (2012). Recurrent word combinations in academic writing by native and non-native speakers of English: A lexical bundles approach. English for Specific Purposes 31:81-92.

Anthony, L. (2014) AntConc (Version 3.4.3) [Computer Software]. Tokyo, Japan: Waseda University. Available from http://www.laurenceanthony.net.

Biber, D., Conrad, S., \& Cortes, V. (2004). 'If you look at...': Lexical bundles in university teaching and textbooks. Applied Linguistics 25:371-405.

Biber, D., \& Conrad, S. (1999). Lexical bundles in conversation and academic prose. In H.H. Hasselgard \& S. Oksefjell (Eds.), Out of corpora: studies in honour of Stig Johansson (pp. 181-189). Atlanta, GA: Rodopi.

Biber, D., Johansson, S., Leech, G., Conrad, S., and Finegan, E. (1999). Longman grammar of spoken and written English. Harlow: Pearson.

Baker, M. (1995). Corpora in translation studies: An overview and suggestions for future research. Target 7:223-243.

Chen, Y. H., and Baker, P. (2010). Lexical Bundles in L1 and L2 Academic Writing. Language Learning \& Technology 14 (2): 30-49.

Cortes, V. (2013). The Purpose of this study is to: Connecting lexical bundles and moves in research article introductions. Journal of English for Academic Purposes 12 (1): 33-43. 
Dontcheva-Navratilova, O. (2012). Lexical bundles in academic texts by non-native speakers. Brno Studies in English 38(2): 37-58.

Granger, S. (2014). A lexical bundle approach to comparing languages: Stems in English and French. Languages in Contrast 14(1):58-72.

Hyland, K. (2008). As can be seen: Lexical bundles and disciplinary variation. English for Specific Purposes 27: 4-21.

Jalilifar, A., Ghoreishi, S.M. \& Roodband, S.A.E. (2017) Developing an inventory of core lexical bundles in English research articles: a cross-disciplinary corpusbased study. Journal of World Languages 1:1-21.

Lee, C. (2013). Using lexical bundle analysis as discovery tool for corpus-based translation research. Perspectives: Studies in Translatology 21(3): 378-395.

McEnery, T. \& Hardie, A. (2012). Corpus linguistics: Method, theory, and practice. Cambridge: Cambridge University Press.

McEnery, T, Xiao. R., \& Tono, Y. (2006) Corpus-based language studies: An advanced resource book. New York: Routledge.

Ngadiman, A. (2013). The lexical phrases employed in the thesis abstracts of English department students. Magister Scientiae 33:93-106.

Novita, H \& Kwary, D.A.(2018). Comparing the use of lexical bundles in Indonesian-English translation by student translators and professional translators. Journal of Translation and Interpreting 10(1):53-74.

Paquot, M. (2013). Lexical bundles and L1 transfer effects. International Journal of Corpus Linguistics 18(3): 391417.

Wei, Y. \& Lei, L. (2011). Lexical bundles in the academic writing of Chinese advanced learners. RELC Journal 42(2):155-166. 
APPENDIX 1

TABLE 2. Most common Indonesian and English LBs in thesis abstracts

\begin{tabular}{|c|c|c|c|c|c|c|c|c|c|c|c|c|}
\hline RANK & Indonesian 3-word LBs & FREQ & F/10000 & Indonesian 4-word LBs & FREQ & F/10000 & English 3-word LBs & $\mathbf{F}$ & F/10000 & English 4-word LBs & $\mathbf{F}$ & F/10000 \\
\hline 1 & penelitian ini adalah & 46 & 29.72 & penelitian ini bertujuan untuk & 20 & 12.92 & this research is & 36 & 21.03 & of this research is & 18 & 10.51 \\
\hline 2 & dalam penelitian ini & 34 & 21.97 & dalam penelitian ini adalah & 18 & 11.63 & one of the & 25 & 14.60 & in this research is & 10 & 5.84 \\
\hline 3 & penelitian ini bertujuan & 22 & 14.21 & digunakan dalam penelitian ini & 12 & 7.75 & in this research & 19 & 11.10 & the purpose of this & 10 & 5.84 \\
\hline 4 & ini bertujuan untuk & 21 & 13.57 & yang digunakan dalam penelitian & 12 & 7.75 & the result of & 18 & 10.51 & is one of the & 9 & 5.26 \\
\hline 5 & hasil penelitian menunjukkan & 15 & 9.69 & ini bertujuan untuk mengetahui & 10 & 6.46 & of this study & 16 & 9.35 & the result of this & 8 & 4.67 \\
\hline 6 & yang digunakan dalam & 15 & 9.69 & metode yang digunakan dalam & 9 & 5.82 & is one of & 14 & 8.18 & used in this research & 8 & 4.67 \\
\hline 7 & data yang digunakan & 12 & 7.75 & penelitian ini adalah untuk & 8 & 5.17 & the purpose of & 13 & 7.59 & of this study is & 7 & 4.09 \\
\hline 8 & digunakan dalam penelitian & 12 & 7.75 & hasil penelitian menunjukkan bahwa & 7 & 4.52 & the results of & 13 & 7.59 & purpose of this research & 7 & 4.09 \\
\hline 9 & merupakan salah satu & 12 & 7.75 & tujuan penelitian ini adalah & 7 & 4.52 & the development of & 12 & 7.01 & result of this research & 7 & 4.09 \\
\hline 10 & yang digunakan adalah & 12 & 7.75 & analisis data yang digunakan & 5 & 3.23 & to determine the & 11 & 6.43 & the results of this & 7 & 4.09 \\
\hline 11 & hasil penelitian ini & 11 & 7.11 & dari penelitian ini adalah & 5 & 3.23 & to know the & 11 & 6.43 & in the form of & 6 & 3.50 \\
\hline 12 & penelitian ini dilakukan & 11 & 7.11 & penelitian ini menggunakan metode & 5 & 3.23 & based on the & 10 & 5.84 & the method used in & 6 & 3.50 \\
\hline 13 & penelitian ini menggunakan & 11 & 7.11 & hasil penelitian ini adalah & 4 & 2.58 & result of this & 10 & 5.84 & this research aims to & 6 & 3.50 \\
\hline 14 & bertujuan untuk mengetahui & 10 & 6.46 & metode penelitian yang digunakan & 4 & 2.58 & the level of & 9 & 5.26 & this research is to & 6 & 3.50 \\
\hline 15 & dari penelitian ini & 10 & 6.46 & penelitian ini adalah metode & 4 & 2.58 & the process of & 9 & 5.26 & this study aims to & 6 & 3.50 \\
\hline 16 & metode yang digunakan & 9 & 5.82 & penelitian ini merupakan penelitian & 4 & 2.58 & this study is & 9 & 5.26 & method used in this & 5 & 2.92 \\
\hline 17 & ini adalah untuk & 8 & 5.17 & pengumpulan data yang digunakan & 4 & 2.58 & used in this & 9 & 5.26 & results of this study & 5 & 2.92 \\
\hline 18 & oleh karena itu & 8 & 5.17 & tujuan dari penelitian ini & 4 & 2.58 & it can be & 8 & 4.67 & the result of the & 5 & 2.92 \\
\hline 19 & penelitian menunjukkan bahwa & 8 & 5.17 & & & & significant effect on & 8 & 4.67 & the results showed that & 5 & 2.92 \\
\hline 20 & tujuan penelitian ini & 7 & 4.52 & & & & according to the & 7 & 4.09 & this research is the & 5 & 2.92 \\
\hline
\end{tabular}




\section{APPENDIX 2}

List of top 100 most frequent three-word core bundles in academic writing (Jalilifar et al. 2017)

\begin{tabular}{|c|c|c|c|c|c|}
\hline $\mathrm{R}$ & Lexical bundle & $F$ & Rank & Lexical bundle & $F$ \\
\hline 1 & as well as & 2686 & 51 & the value of & 493 \\
\hline 2 & the number of & 1976 & 52 & a variety of & 487 \\
\hline 3 & based on the & 1518 & 53 & related to the & 484 \\
\hline 4 & in terms of & 1458 & 54 & a series of & 471 \\
\hline 5 & the use of & 1432 & 55 & the formation of & 466 \\
\hline 6 & the effect of & 1290 & 56 & need to be & 458 \\
\hline 7 & due to the & 1208 & 57 & the process of & 453 \\
\hline 8 & the fact that & 1089 & 58 & the work of & 452 \\
\hline 9 & according to the & 969 & 59 & in relation to & 439 \\
\hline 10 & a number of & 965 & 60 & show that the & 439 \\
\hline 11 & the development of & 910 & 61 & the form of & 439 \\
\hline 12 & on the other & 907 & 62 & it can be & 435 \\
\hline 13 & the result of & 893 & 63 & that can be & 430 \\
\hline 14 & the presence of & 810 & 64 & as shown in & 425 \\
\hline 15 & the end of & 802 & 65 & effect of the & 425 \\
\hline 16 & the role of & 780 & 66 & can be used & 416 \\
\hline 17 & the case of & 779 & 67 & be able to & 412 \\
\hline 18 & the relationship between & 775 & 68 & the present study & 412 \\
\hline 19 & the importance of & 765 & 69 & understanding of the & 408 \\
\hline 20 & the other hand & 763 & 70 & at the end & 407 \\
\hline 21 & as a result & 755 & 71 & the basis of & 405 \\
\hline 22 & lead to the & 755 & 72 & a result of & 403 \\
\hline 23 & with respect to & 732 & 73 & the amount of & 399 \\
\hline 24 & such as the & 708 & 74 & the difference between & 395 \\
\hline 25 & at the same & 699 & 75 & the history of & 392 \\
\hline 26 & in the case & 651 & 76 & is based on & 385 \\
\hline 27 & the same time & 650 & 77 & the university of & 385 \\
\hline 28 & the context of & 621 & 78 & value of the & 385 \\
\hline 29 & in addition to & 601 & 79 & nature of the & 383 \\
\hline 30 & a set of & 600 & 80 & use of the & 383 \\
\hline 31 & in this case & 589 & 81 & for example the & 382 \\
\hline 32 & analysis of the & 584 & 82 & the quality of & 382 \\
\hline 33 & focusing on the & 580 & 83 & the analysis of & 377 \\
\hline 34 & the concept of & 576 & 84 & used in the & 376 \\
\hline 35 & well as the & 571 & 85 & the majority of & 375 \\
\hline 36 & the study of & 550 & 86 & of the studies & 374 \\
\hline 37 & in other words & 549 & 87 & be used to & 373 \\
\hline 38 & end of the & 541 & 88 & appears to be & 359 \\
\hline 39 & associated with the & 540 & 89 & difference between the & 358 \\
\hline 40 & in this study & 539 & 90 & the absence of & 358 \\
\hline 41 & in the same & 528 & 91 & likely to be & 356 \\
\hline 42 & the level of & 527 & 92 & results of the & 355 \\
\hline 43 & the nature of & 524 & 93 & the question of & 355 \\
\hline 44 & because of the & 521 & 94 & in the following & 347 \\
\hline 45 & in this paper & 519 & 95 & refers to the & 347 \\
\hline 46 & suggest that the & 518 & 96 & the field of & 345 \\
\hline 47 & depend on the & 517 & 97 & in the form & 338 \\
\hline 48 & in the context & 509 & 98 & found to be & 331 \\
\hline 49 & the impact of & 502 & 99 & a range of & 330 \\
\hline 50 & more likely to & 501 & 100 & the existence of & 330 \\
\hline
\end{tabular}


List of common four-word core bundles in academic writing (Jalilifar et al. 2017)

\begin{tabular}{|c|c|c|c|c|c|}
\hline$\overline{\text { Rank }}$ & Lexical bundle & Tokens & Rank & Lexical bundle & Tokens \\
\hline 1 & at the same time & 607 & 41 & in the process of & 135 \\
\hline 2 & in the case of & 594 & 42 & the development of the & 135 \\
\hline 3 & as well as the & 570 & 43 & in the development of & 134 \\
\hline 4 & on the other hand & 559 & 44 & it is difficult to & 133 \\
\hline 5 & on the one hand & 544 & 45 & the use of the & 133 \\
\hline 6 & in the context of & 496 & 46 & to be able to & 131 \\
\hline 7 & the end of the & 448 & 47 & by the fact that & 130 \\
\hline 8 & at the end of & 386 & 48 & the context of the & 129 \\
\hline 9 & as a result of & 348 & 49 & the results of the & 129 \\
\hline 10 & in the form of & 317 & 50 & $\overline{\text { in contrast to the }}$ & 124 \\
\hline 11 & to the fact that & 272 & 51 & to the development of & 123 \\
\hline 12 & it is important to & 264 & 52 & in the sense that & 122 \\
\hline 13 & on the basis of & 255 & 53 & can be found in & 119 \\
\hline 14 & in terms of the & 254 & 54 & a result of the & 118 \\
\hline 15 & one of the most & 249 & 55 & at the level of & 116 \\
\hline 16 & is one of the & 246 & 56 & in other words the & 115 \\
\hline 17 & the nature of the & 226 & 57 & with respect to the & 114 \\
\hline 18 & in this case the & 213 & 58 & with the exception of & 112 \\
\hline 19 & can be used to & 212 & 59 & it is necessary to & 111 \\
\hline 20 & at the university of & 209 & 60 & the other hand the & 111 \\
\hline 21 & in the present study & 201 & 61 & that there is no & 108 \\
\hline 22 & the fact that the & 201 & 62 & the basis of the & 107 \\
\hline 23 & a wide range of & 191 & 63 & it is possible that & 106 \\
\hline 24 & the beginning of the & 185 & 64 & as one of the & 104 \\
\hline 25 & in addition to the & 179 & 65 & it should be noted & 104 \\
\hline 26 & the rest of the & 174 & 66 & as well as a & 103 \\
\hline 27 & in the absence of & 167 & 67 & the case of the & 103 \\
\hline 28 & the difference between the & 163 & 68 & the course of the & 95 \\
\hline 29 & at the beginning of & 159 & 69 & the development of a & 95 \\
\hline 30 & that there is a & 159 & 70 & the level of the & 95 \\
\hline 31 & in the field of & 158 & 71 & the purpose of this & 93 \\
\hline 32 & of the most important & 155 & 72 & as a result the & 92 \\
\hline 33 & is based on the & 151 & 73 & in the study of & 91 \\
\hline 34 & at the time of & 150 & 74 & can be seen in & 86 \\
\hline 35 & the time of the & 150 & 75 & for example in the & 85 \\
\hline 36 & the relationship between the & 141 & 76 & the presence of the & 84 \\
\hline 37 & it is possible to & 140 & 77 & in a number of & 82 \\
\hline 38 & it is clear that & 139 & 78 & for the purpose of & 79 \\
\hline 39 & for the first time & 137 & 79 & in the next section & 74 \\
\hline 40 & in the same way & 137 & 80 & the same time the & 70 \\
\hline
\end{tabular}

